\title{
Literature in Multiliteracy Perspective
}

\author{
Teguh Trianton \\ Faculty of Teacher Training and Education \\ Universitas Muhammadiyah Purwokerto \\ Purwokerto, Indonesia \\ teguhtrianton@ump.ac.id \\ Septi Yulisetiani \\ Doctoral Program of Bahasa Indonesia Education \\ Universitas Sebelas Maret Surakarta \\ Surakarta, Indonesia \\ septiyulisetiani@gmail.com
}

\begin{abstract}
This article discusses the importance of literary criticism in multiliteracy perspective. Literary work is an autonomous object. But it has close relationship with the various issues and cultural aspects that underlie the author's life. Literary works are also dealing with readers with diverse cultural backgrounds. In the development of literary works, they encounter transformation, metamorphosis, or switch mode into film, theater performances, musicalization, comics, digitalization and so forth. Literary works undergo the process of reproduction of various, multilevel and intertext sign systems. The discourse construction in it is not independent, but interconnected with the various discourses beyond. Therefore, the interpretation and criticism of literary works is done with multiliteracy; multiperspective, multimodality, and multidisciplinary. From these points, the concept of literary criticism in multiliteracy perspective begins. Literary criticism is the culmination of the literary works appreciation. Literary criticism in multiliteracy perspective can produce comprehensive meaning because the message is not only seen from a single perspective but also involving various sign systems and other knowledge aspects.
\end{abstract}

Keywords;literature; multimodality; multiliteracy

\section{INTRODUCTION}

Literary criticism is part of literary studies. Literary studies cover three areas namely; literary theory, literary history, and literary criticism. Literary criticism is the study that directly discusses literature that focuses on assessment. Literary criticism is the study of good or bad review of literary works. The consideration is accompanied by logical and argumentative reasons about the content and the form of the literary works. Literary criticism is also understood as an explanation and judgment on the quality of literary works $[1,2]$.

Literary criticism is often regarded as censure of literary work, but it is accompanied by logical description and consideration. Criticism is actually the response or opinion against particular object. Good literary criticism can only be written with careful observation, precise comparison, and fair consideration of good and bad quality, value, and truth of the literary work. Writing criticism means providing adequate guide to the reader to assess the quality of work. A qualified literary critique is an assessment of literary works involving a set of basic concepts or theories, different points of view, and literary history. Such literary criticism will result in a comprehensive assessment.
Literary criticism has key aspects that include; analysis, interpretation, and evaluation or assessment. Literary work is actually a complex structure, hence to understand it, we need to analyze first. Analysis is a step in interpretation or exegesis. Interpretation is the exegesis of literary works on all aspects of literary works [3].

A literary work typically contains broad ideas, complex structures, and written in beautiful language medium. Therefore, literary works need to be interpreted to clarify the message of the author wishes to convey. Simply put, interpretation is the explanation from language point of view in literary work by means of analysis, paraphrasing, and commentary. Interpretations typically centered on darkness, representation, depiction, ambiguity, or indirectly expression in the messages delivery that conducted with the use of complex sign systems.

Literary works are works of art. Therefore, it should be explained to what extent the value of the art of the literary works. There are three main activities in literary criticism, namely analysis, interpretation, and assessment. The analysis and the interpretation of literary works should be related to the assessment. The activities of literary criticism can not be separated as form of the highest appreciation of the literary works, all of which 
are closely interrelated and mutually determine simultaneously.

To analyze, interpret, and assess literary works required the orientation of literary works that determine the direction or style of literary criticism. The orientation of the literary work is based on the whole situation of literary works: nature (life), reader, writer, and literary work. Based on those situations, there are four orientations, namely orientation

(1) mimetic, (2) pragmatic, (3) expressive, and (4) objective [4].

Besides literary orientation, criticism process of writing is also distinguished by its forms, methods (applying), types of literary criticism, and writer of literary criticism (critics). Based on its form, literary criticism can be classified as critique of theoretical literature and critique of practical literature (applied) [5]. According to the method (application) there are three types of literary criticism, namely inductive criticism, judicial criticism, and impressionistic criticism. Inductive criticism analyzes the elements of literary works according to the phenomena objectively. Judicial criticism tries to analyze and explain the effects of literary works based on its content, organization, technique and style, according to individual critics' considerations on the basis of the general standards of the excellence and the extraordinary of literary work. Impressionistic criticism attempts to describe the characteristics felt in certain parts of a literary work. This criticism tries to express the responses, imprints (impressions) of critics that arise directly at the reading of literary works. Impression is the aesthetic image of the audience towards the object of art that is enjoyed [3]. Based on the critics and its feature of criticism, literary criticism can be categorized as literary criticism and academic criticism. Literary criticism is written by writers, usually expressive and impressionistic. Academic criticism is a literary critique written by literary and scholarly scholars [6].

The function of literary criticism can be classified into three, firstly for the development of literary science, secondly for the development of literature and thirdly for the lighting of society in general. Literary criticism can help arrange the theory of literature and the history of literature. Literary criticism contributes to development of a nation literature by explaining the literary work of the good and bad of literary works and showing areas of literary affairs. Thus man of letters can take advantage from literary criticism so they can develop writing literary tradition. Literary criticism describes (analyzes, interprets and assess) literary works. Thus, the public may utilize this literary critique for understanding and appreciation of literary works $[7,8]$.

\section{LiTERACY AND MULTILITERACY}

Literacy is someone's ability to search, collect, interpret, use, evaluate and communicate information from various sources effectively. At first, the concept of literacy is understood as the ability to read and write only. Literacy is attributed to the ability of oral and written communication solely. Moreover, in the universal declaration of human rights (HAM) education is defined as a basic right, literacy has also been regarded as the right of everyone. "A right primarily understood as a set of technical skills: reading, writing and calculating" [8]. This concept, in the context of Indonesia is called by the term kemelekhurufan, or the ability to read and write.

Along with the development of science and technology, it impacts on changes in systems and communication media. The climax is the discovery of digital technology that introduces us to the era of convergence. The information is not only shared in form that can be read and written but also be transmitted on different platforms. The convergence changes verbal information into form of the digitization. The different types of content (data, audio, voice, video) is placed in similar format and delivered continuously through a wide variety of information technology such as computers, mobile phones, televisions, and others.

The phenomenal events that occurred in the development of communication and technology (1950s) were the emergence of various electronic media such as telephone, film, radio and television. Came afterward in the 1980s, the emergence of technology of the digital and internet media. The advent of digital media can extend the reach of information at rapid rate, has led -in the context of information society- a new intellectual, semiotic, communicative and cultural climate change. This marks the effect on individuals, work relations and social development [9].

At the beginning of its appearance, digital communication media is called as new media. The new media are grouped into four categories. First, interpersonal communication media such as telephone, mobile phone, e-mail. Second, interactive media play such as computers, video games, games on the internet. Third, information search media in the form of portals or search engines. Fourth, collective participation media such as the use of the internet to share and exchange information, opinions, experiences, and establish relationship through computer where its use is not only for the tool, but also for the affection and emotional agent [10].

The communities in the digitalized information and globalization era are characterized by a life that is very familiar with the development of science, technology, and art. The community is required to have the basic capability of information literacy [11] in order to survive in the global competition. For that reasons, the advancement of literacy culture plays an important role in meeting the needs of society. Therefore, the definition of literacy also undergoes changes and progress.

Period change and human culture are growing rapidly. Human can obtain much information through the variety of media. The concept of literacy does not stop at the limits of keberaksaraan (the ability of read and write). The term literacy is turned multiliteracy that many different text types and media that people engage with. It incorporates the different uses of language online, on mobile phones and tablets, and 


\section{incorporates broader understanding of text types and audiences $[12,13]$. \\ In short, there are four phases of literacy} development. First, classical literacy is the ability to read, write, and understand information; second, audiovisual literacy, which connects to electronic media such as film and television, focusing on images and series of images; third, digitalization of information or digital literacy originating from computers and digital media; and fourth, media literacy is a phase of media convergence that combines electronic media and digital media. This media literacy includes various forms of literacy: reading, writing, audiovisual, digital and media convergence [9].

The concept of multiliteracy is derived from the following comprehensive literacy definition.

Literacy is the use of socially-, and historically-, and culturally-situated practices of creating and interpreting meaning through texts. It entails at least a tacit awareness of the relationships between textual conventions and their context of use and, ideally, the ability to reflect critically on the relationships. Because it is purpose-sensitive, literacy is dynamic - not static - and variables across and within discourse communities and cultures. It draws on a wide range of cognitive abilities, on knowledge of written and spoken language, on knowledge of genres, and on cultural knowledge [14].

Multiliteracy actually arises in response to the emergence of various moda in the process of message delivery and interpretation of meaning. Moda is a semiotic source that is socially and culturally formed to make meaning. The types of these modas are language (oral, written), images, music, body movements, and video. These modas are commonly used in representation and communication [15].

Phenomena and various objects are the products of social activities that have meaning. Each moda has its meaning depending on its social context. The process of meaning interpretation cannot be separated from the braid and the network of the moda. In this context, the meaning is interpreted based on multimodality. Thus phenomena or objects that become messages will get more comprehensive meaning.

Multimodality is a multidisciplinary approach to understand the communication and to represent more than just language events. This approach is developed to address the issue of change in contemporary society. The multimodal approach provides concepts, methods, and frameworks for the collection and analysis of information in various forms such as pictures, videos, body movements, language and so on.

Thus, multiliteracy is the ability of person to search, collect, interpret, use, evaluate and communicate the information from various sources and multimodality effectively, involving social, historical, and cultural situations to gain comprehensive meaning through the text braided and network.

\section{MultiliteraCY IN LITERARY CRITICISM}

Literary works are works of art that are built with the main medium in the form of language. Literary work typically contains broad ideas, complex structures, and is implicitly conveyed through beautiful figurative language. To get comprehensive meaning, literary works need to be interpreted to clarify the message wants to be conveyed by the author.

Interpretation is explanation from particular point of view on literary works by means of analysis, paraphrasing, and commentary. Interpretations typically center on darkness, representation, depiction, ambiguity, or indirect expression in the delivery of messages made with the use of complex sign systems. Interpretation is one of the steps that must be taken to make an assessment or criticism.

There are three main activities in literary criticism, namely analysis, interpretation, and assessment. The activities of literary criticism cannot be separated as form of the highest appreciation of literary works, all of which are closely interrelated and mutually determine simultaneously. Qualified literary critique is an assessment of a literary work involving a set of concepts or theories, various perspectives, and literary history. This literary criticism will produce a comprehensive assessment.

In the age of digitalized information technology, an author and literary reader are in multilevel sign system network. The work they create and read can not be separated from multimodality. Therefore, the procedures of interpretation and literary criticism experience new chapter. The approach in literary criticism is not monodisciplinary. Literary criticism is carried out with interdisciplinary or multidisciplinary approach because the issues in it relate to various sciences. This is the approach that allows the practice of multiliteracy studies in literary criticism.

Based on its characteristics, this interdisciplinary approach can be divided into four types of approaches: interdisciplinary approaches, multidisciplinary approaches, transdisciplinary approaches, and crossdisciplinary approaches. Interdisciplinary is intensive interaction between one or more disciplines, whether directly related or not, through research programs, with the aim of integrating concepts, methods, and analysis. Multidisciplinary is the incorporation of several disciplines to answer or solve particular problem. Transdisciplinary is the attempt to develop new theory or axiom by building relationships and relevance among various disciplines [16].

Multiliteracy and interdisciplinary studies in the context of literary studies is a necessity, because literary works are actually mosaics or excerpts of various objects of knowledge in network of texts or intertextuality. The concept of intertextual relationship presupposes the existence of more open frame of reference, in each interpreting the presence of stock of knowledge of scientific truth, remembering the truth of each text is 
always in the texts braided overpass (transposition) with other texts $[17,18]$.

Various types of texts are used as sources or materials for the interpretation and assessment of literary works. This principle is in accordance with the concept of multiliteracy, that various modalities can be used in scientific studies. Various text genres are very important to be analyzed. The development of science and technology led to the creation of various texts with various moda. Text is reproduced in electronic digital format; verbal, audial and visual, text in the form of films or videos, can be accessed online, and so on. Therefore, the interpretations of literary text undoubtedly do with multiliteracy involving various tools, approaches, features, and multidisciplines in an intertextual network.

The multimodal principle becomes the basis for the development of the literacy learning model. Multimodal is the concept of "meaning and knowledge are built up through various modalities including images, texts, symbols, and interactions". Multimodal concept in language learning is language arts education can no longer ignore the way that our social, cultural, and economic world now requires facility with texts and practice involving the full range of representational modes [19, 20].

This multimodal concept in 1996 was introduced into multiliteracy concept. Human not only reads or writes, but he also reads and writes with certain genres that involve social, cultural, and political goals. In an effort to enhancing the competence multiliteracy, use of graphics, images, text setting, photos, presentations, gestures, dramatic play, either in print or electronic media is the source and interesting learning. Mode is essential to be used as a form of social and cultural resources to make meaning [21, 22, 23, 24, 25, 26, 27].

There are four dimensions of multiliteracy: first, situated practice, which describes the experience of one's life. Second, the overt instruction, which involves metalanguage, to deconstruct the concepts and multimodality ways in which meaning is constructed. Third, critical framing of the cultural and social context means introduced and understood as social and cultural context. Fourth, transformed practices are effort to transform the meaning of the social and cultural dimensions [21].

Multiliteracy practices in literary criticism are based on multimodal literacy aspects that include linguistic competence, visual competence, audio competence, gestural competence, and spatial competence. The study of literary works will be done by connecting various texts, sign systems, and relevant messages. A critic will undoubtedly use all his knowledge that has been obtained through various modalities to interpret literary works. Literary works will be associated with various texts such as films, dramas, theaters, television programs as analysis materials. Linguistic competence contributes to the analysis of spoken language as in daily life in the structure, organization, language style, personality of the characters, and the cultural context of society in character life. Spatial competence relates to the analysis of the use of space and its influence on character figures. Gestural competence focuses on the analysis of actions played by characters. Visual competence is concerned with how things can be observed in terms of matters, attitudes or goods.

\section{AFTERWORD}

The essence of literature is cultural product, it is never written in a nil situation of culture. The process of creating literary works automatically (undoubtedly) involves the various (multidisciplinary) knowledge possessed by the author. This multidisciplinary is derived from multimodality with multiliteracy. Therefore, literary works should be placed within the relevant text network. Literary works should also be interpreted by involving various disciplines of knowledge pertaining to the object of study, connected (intertextuality) with various texts of various moda. This process is known as literary criticism in multiliteracy perspective.

Literary criticism has positive contribution to the development of literature as mirror of the development of human civilization. Therefore the perspective of literary criticism needs to be harmonized with cultural development. Criticism is no longer monodisciplinary. A good criticism is the criticism that is made by involving all relevant texts, from various modes, and multidisciplinary. The work of literary criticism becomes the place of the assessment disclosure of the comprehensive, simultaneous, and comprehensive literature.

\section{References}

[1] Jassin, H.B., Kesusastraan Indonesia Modern Dalam Kritik dan Esei, Jakarta: Gunung Agung, 1985.

[2] Wellek, R., dan A. Warren, Teori Kesusastraan, (Terj. Melani Budianta), Jakarta: Gramedia, 2014.

[3] Abrahm, M.H. A Glosary of Literary Terms, New York: Holt Rinehart and Winston, 1981.

[4] Abrams, M.H. The Mirror and the lamp: Romantic Theory and the Critical Tradition. New York: Oxford University Press, 1979.

[5] Pradopo, R.D. Kritik Sastra Indonesia Modern, Yogyakarta: Gama Media, 2002.

[6] Pradopo, R.D. Beberapa Teori Sastra, Metode Kritik, dan Penerapannya, Yogyakarta: Pustaka Pelajar, 2007.

[7] Pradopo, R.D. Prinsip-Prinsip Kritik Sastra, Yogyakarta: UGM Press, 2011.

[8] UNESCO, The Plurality Of Literacy And Its Implications For Policies And Programmes. Paris: United Nations Educational, Scientific and Cultural Organization, 2004. Available at http://unesdoc.unesco.org/images/0013/001362/136 246e.pdf, Accessed: 28-12-2016 
[9] Baran, Stanley J. Introduction To Mass Communication: Media Literacy and Culture, Network: The Mc. Graw - Hill Companies, 2004.

[10] Mc Quail, D. Communication and the Public Interst, London: Sage Publications, 2002.

[11] Perry, K. "What is Literacy? -A critical overview of sociocultural perspectives," Journal of Language and Literacy Education [Online], 8(1), pp. 50-71, 2012. Available at http://jolle.coe.uga.edu/wpcontent/uploads/2012/06/What-isLiteracy KPerry.pdf

[12] Fielding, R. "Considering biliteracy and multiliteracies in the primary classroom", dalam Johnston, J. (Ed), Contemporary issues in Australian literacy teaching, Brisbane: Primrose Hall Publishing Group, 2012.

[13] Kitson, L., Fletcher, M. and Kearney, J. "Continuity and Change in Literacy Practices: A Move towards Multiliteracies" in The Journal of Classroom Interaction, 41/42, (2/1), pp. 29-41, 2007. Stable http://www.jstor.org/stable/23869446. Accessed: 16-08-2017.

[14] Kern, R. Literacy and Language Teaching, Oxford: Oxford University Press, 2000.

[15] Kress, G. Carey Jewitt, Jon Ogborn and Charalampos Tsatsarelis, Multimodal Teaching and Learning: The rhetorics of the science Classroom, Continuum: London and New York, 2001.

[16] Prentice, A.E. "Introduction" dalam Information Science - The Interdisciplinary Context, (ed. J. M. Pemberton dan A.E. Prentice), New York : NealSchuman Publishers, 1990.

[17] Kristeva, J. Revolution in Poetic Language (European Perspectives Series), Columbia: Columbia University Press, 1974.

[18] Kristeva, J. Desire in Language: A Semiotic Approach to Literature and Art, Columbia: Columbia University Press, 1979.
[19] Vasquez, V. Getting Beyond "I Like the Book": Creating Space for Critical Literacy in K-6 Classrooms, Newark, DE: International Reading Association, 2003.

[20] Siegel, M. "Rereading the Sign: Multimodal Tranformations in the Field of Literacy Education" in Language Arts, 84 (1), 2006. Available at www.proquest.umi.pqd/web, Accessed: 16-06-2017

[21] New London Group, A Pedagogy of Multiliteracies: Designing Social Futures, Harvard Educational Review, 66, 1996.

[22] Coughlan, S. "Advocating for the Arts in an Age of Multiliteracies" in Language Arts, 86 (2), 2008. Available at www.proquest.umi.pqd/web

[23] Bazemer, J. \& Kress, G. "Writing in Multimodal Texts: A Social Semiotic Account of Designing for Learning," in Written Communication, 25 (2), 2008.

[24] Tan, J. Pei-Ling and McWilliam, Erica L., "From literacy to multiliteracies: diverse learners and pedagogical practice", Pedagogies: An International Journal, 4 (3), pp. 213-225, 2009.

[25] Barron, N. G. Review Buku: "Multiliteracies: Literacy: Learning and the Design of Social Futures," in Technical Communication Quarterly, Autumn, 16 (4), 2007.

[26] Hasset, D. D., dan Jen Scoot Cur-wood. "Theories and Practice of Multimodal education: The Instructional Dynamics of Picture Book and Primary Classroom" in The Reading Teacher 63 (4), 2009, International Reading Association. Available at www.proquest.umi.pqd/web, Accessed: 16-072017

[27] Graham, M. S., Sheila Benson, Lisa Storm Fink, "A Springboard Rather Than a Bridge: Diving into Multimodal Literacy" in English Journal (High School Edition) Urbana: 200 (153) November 2010. 